УДК 615.22:364.692:616.1

DOI https://doi.org/10.11603/2312-0967.2020.1.10905

\title{
ДОСЛІДЖЕННЯ НОРМАТИВНО-ПРАВОВОЇ БАЗИ У СФЕРІ ЗАБЕЗПЕЧЕННЯ ДОСТУПНОСТІ ЛІКІВ ДЛЯ НАСЕЛЕННЯ
}

\author{
В. М. Назаркіна \\ Національний фрармацевтичний університет, Харків \\ victory.nazarkina@gmail.com
}

ІНФОРМАЦІЯ

Надійшла до редакції / Received: 10.02.2020

Після доопрацювання / Revised: 17.02.2020

Прийнято до друку / Accepted: 20.02.20209

\section{Ключові слова:}

ціноутворення;

лікарські засоби;

доступність ліків;

нормативно-правова база;

державне регулювання;

нормативно-правовий акт.
АНОТАЦІЯ

Мета роботи. Аналіз і систематизація нормативно-правової бази у ссрері забезпечення доступності ліків для населення.

Матеріали і методи. Нормативно-правові акти, аналітичні документи, офріційні сайти органів влади, наукові праці вітчизняних вчених щодо державного регулювання цін на лікарські засоби; аналіз історичний, логічний, узагальнення і систематизація.

Результати й обговорення. В контексті забезпечення державою гарантій доступності медичної та фрармацевтичної допомоги для населення держава здійснює регулювання цін на ліки шляхом декларування цін, встановлення граничних націнок, ресрерентного ціноутворення. За умов відсутності в Україні обов'язкового медичного страхування впроваджуються пілотні проекти та урядові програми щодо підвищення доступності ліків для населення. За період незалежності державою прийнято низку нормативно-правових актів у сорері фрармацевтичного ціноутворення, а саме: 25 Постанов КМУ, більше 20 наказів МО3 України. За результатами опитування працівників аптек, часта зміна та суперечливість нормативної бази є однією з основних проблем, що зумовлює низьку ефективність системи державного регулювання фрармацевтичної діяльності. Це, у свою чергу, впливає на якість надання фрармацевтичної допомоги населенню.

Висновки. 3 метою створення едективної системи цінового регулювання пропонується оптимізувати нормативно-правову базу в напрямку кодисрікації, що дозволило б оперативно вносити зміни, уникати правових колізій та, нарешті, підвищити якість та доступність фрармацевтичної допомоги для населення.
Вступ. Забезпечення доступності лікарських засобів (Л3) для населення з року в рік визначається як один із пунктів Плану пріоритетних дій Уряду та є одним із головних завдань Державної стратегії реалізації державної політики забезпечення населення ЛЗ на період до 2025 р., затвердженої ПКМУ № 1022 від 5.12.2018 р. При цьому особливо важливо досягти балансу інтересів системи охорони здоров'я (О3) щодо стримування витрат і підвищення ефективності, гарантії доступності Л3, населення - щодо безпе- ки, високої якості та доступності ЛЗ та ефрективного лікування і промисловості - щодо забезпечення рентабельності, розвитку вітчизняної дослідницької промисловості, захисту прав інтелектуальної власності, створення та збереження робочих місць, державної підтримки.

Витрати державного бюджету в Україні на ОЗ як частка ВВП наразі залишаються стабільно низькими. Так, за останні роки вони становили до 3 \%, що значно нижче середнього показника для країн Європей-

ISSN 2312-0967. Фармацевтичний часопис. 2020. № 1 
ського регіону ВОО3 (5 \%) та ЄС (6 \%). За умов відсутності системи медичного страхування левову частину витрат на лікування українці оплачують з власної кишені. Питома вага витрат пацієнтів у сумарних видатках на О3 сягнула $48 \%$ - це один 3 найвищих показників для Європи. Отже, Україна опинилася серед 36 країн із катастрофічними особистими витратами громадян на О3 (понад 25 \% від доходів домогосподарства) [1]. Статистичні дані свідчать, що в Україні щороку приблизно 600 тис. домогосподарств зазнають значних фрінансових витрат на О3 [2]. За таких умов проблема доступності ЛЗ набуває особливої актуальності та потребує невідкладного вирішення. Серед основних причин: низький рівень доходів населення, неефективна цінова політика, висока імпортозалежність ринку; неврегульованість рецептурного відпуску ЛЗ.

Для підвищення доступності ЛЗ держава здійснює централізовані закупівлі Л3, упроваджує референтне ціноутворення, реалізує пілотні проекти та урядові програми з відшкодування вартості Л3. Аптеки спільно з виробниками ЛЗ реалізовують соціальні програми «Orange Card», «Медікард», «Про-прайс», «Abbottcard» та «МДМ», що спрямовані на підвищення доступу до сучасних, ефективних Л3, які використовують у кардіології, онкології, ендокринології, пульмонології, офртальмології. Але, на жаль, ці ініціативи не покривають зростаючої потреби у лз. Необхідний системний науково обґрунтований підхід з урахуванням власного попереднього та позитивного закордонного досвіду в регулюванні цін і забезпеченні доступності ЛЗ.

Проблема доступності ЛЗ та її нормативно-правового регулювання знаходиться у фрокусі уваги багатьох вітчизняних науковців, журналістів і громадськості та висвітлюються у наукових працях А. С. Немченко, К. Л. Косяченка, В. М. Хоменка, Л. М. Дешко та ін. [3-7]. За умов реформування галузі ОЗ та впровадження низки нормативно-правових актів (НПА), пов'язаних із впровадженням референтного ціноутворення на Лз та відшкодування їх вартості, проблема їх узгодження та оптимізації нормативної бази набуває особливої актуальності і потребує системного підходу до вирішення.

Мета роботи - аналіз і систематизація нормативно-правової бази у сорері забезпечення доступності ліків для населення.

Матеріали і методи. Нормативно-правові акти, аналітичні документи, офріційні сайти органів влади, наукові праці вітчизняних вчених щодо державного регулювання ціноутворення на Л3; аналіз, узагальнення і систематизація.

Результати й обговорення. Проблеми ціноутворення на ЛЗ у контексті стримування зростаючих витрат на О3 за умов обмежених ресурсів розглядаються як на глобальному рівні, так і на рівні окремих держав. Згідно з основними Цілями сталого розвитку всі держави-члени ООН до 2030 р. мають досягти загального охоплення послугами О3 (Universal Health Coverage - UHC). В усіх країнах Європейського регіону ВОО3 (у т. ч. в Україні) створено механізми для підвищення доступності ЛЗ для населення, зокрема, передбачене безоплатне отримання пацієнтами ЛЗ в стаціонарі. При цьому існують значні відмінності у розробці та реалізації політики щодо контролю цін та відшкодування витрат на лз для амбулаторного лікування [3].

Відповідно до європейського законодавства країни-члени ЄС вільно реалізують політику ціноутворення і реімбурсації у сорері фрармацевтичного забезпечення. При цьому в ЄС існують загальні процедурні норми, встановлені Директивою Ради Європи 89/105/EEC [8]. Норми вказаної Директиви спрямовані на забезпечення прозорості в політиці ціноутворення і відшкодування на національному рівні і недопущення виникнення дестабілізації у ссрері забезпечення Л3 на внутрішньому ринку країн-членів $€$. При цьому головна мета - національні системи повинні досягти адекватного балансу між стримуванням витрат, виведенням на ринок дорогих інноваційних препаратів і доступом пацієнтів до ЛЗ. Даним документом встановлюються основи політики ціноутворення для ЛЗ у контексті їхнього включення в систему загального страхування, тобто для Л3, у витратах на які бере участь держава. При цьому дія Директиви не поширюється на сегмент державних закупівель і добровільних договірних відносин між компетентними органами та власником реєстраційного посвідчення.

Уряди країн-членів ЄС як основні покупці ЛЗ з метою оптимізації витрат спрямовують регуляторні впливи на контроль обсягу, непрямий контроль цін і контроль прибутку [3]. Так, контроль обсягу обмежений «позитивними», або «негативними» переліками та типом товарів, які мають бути відшкодовані відповідно до національної системи ОЗ (страхової системи). Контроль прибутку може бути встановлений національним законодавством або адміністративними актами або може бути результатом переговорів між національним урядом і фрармацевтичною промисловістю [4].

Найчастіше основним критерієм при ухваленні відповідних політичних рішень щодо відшкодування або контролю цін є власне Лз (така система називається «product-specific» і застосовується у 32 з 45 країн Європи) або захворювання (disease-specific). Додатково можуть братися до уваги конкретні групи населення («population groups-specific»), що мають право на компенсацію вартості Л3 (інваліди, хворі 3 хронічними захворюваннями, діти, ветерани, безробітні тощо). В деяких країнах ЄС підставою для відшкодування $€$ перевищення суми встановлених загальних витрат на лз протягом певного періоду (схема «consumption-based») [4].

ISSN 2312-0967. Pharmaceutical review. 2020. № 1 


\section{Pharmaceutical legislation}

Відповідно до ст. 49 Конституції України держава створює умови для ефективного і доступного для всіх громадян медичного обслуговування. У державних і комунальних 303 медична допомога надається безоплатно. 3 метою забезпечення державних гарантій щодо доступності ОЛЗ державою прийнято низку НПА, серед них: 25 Постанов КМУ та більше 20 на- казів МО3 України з відповідними змінами та доповненнями [9].

3 метою систематизації нормативно-правової бази [10] нами проведено аналіз нормативно-правових актів з регулювання цін на ЛЗ в історичному аспекті. До таблиці 1 включено НПА, що є чинними на даний момент.

\section{Таблиця 1}

Систематизація нормативно-правової бази у сфері ціноутворення на лікарські засоби

\begin{tabular}{|c|c|c|c|}
\hline НПА & $\begin{array}{c}\text { Дата } \\
\text { прийняття }\end{array}$ & Стисла характеристика & $\begin{array}{l}\text { К-ть } \\
\text { ред }\end{array}$ \\
\hline 1 & 2 & 3 & 4 \\
\hline \multicolumn{4}{|c|}{ Закони України } \\
\hline Про лікарські засоби & 04.04.1996 & $\begin{array}{l}\text { Державна політика у ссрері фармацевтичного } \\
\text { забезпечення населення }\end{array}$ & 33 \\
\hline Про ціни та ціноутворення & 21.06 .2016 & $\begin{array}{l}\text { Використовуються вільні, фріксовані та регульовані } \\
\text { ціни і тарифри }\end{array}$ & 5 \\
\hline $\begin{array}{l}\text { Основи законодавства України про } \\
\text { охорону здоров'я }\end{array}$ & 19.11.1992 & $\begin{array}{l}\text { Правові, організаційні, економічні та соціальні } \\
\text { засади О3 в Україні }\end{array}$ & 50 \\
\hline $\begin{array}{l}\text { Про запобігання фрінансовій } \\
\text { катастрофрі }\end{array}$ & 27.03 .2014 & $\begin{array}{l}\text { Введення податку на додану вартість (ПДВ) на } \\
\text { лікарські засоби за ставкою } 7 \text { \% }\end{array}$ & 10 \\
\hline $\begin{array}{l}\text { Про державні фрінансові гарантії } \\
\text { медичного обслуговування населення }\end{array}$ & 19.10.2017 & $\begin{array}{l}\text { Державні фрінансові гарантії надання медичних } \\
\text { послуг та лЗ за кошти бюджету }\end{array}$ & 4 \\
\hline \multicolumn{4}{|c|}{ Постанови КМУ } \\
\hline $\begin{array}{l}\text { № } 1303 \text { «Про впорядкування } \\
\text { безоплатного та пільгового відпуску } \\
\text { ЛЗ за рецептами лікарів у разі } \\
\text { амбулаторного лікування окремих груп } \\
\text { населення та за певними категоріями } \\
\text { захворювань» }\end{array}$ & 17.08.1998 & $\begin{array}{l}\text { Забезпечення населення необхідними лЗ при } \\
\text { амбулаторному лікуванні } \\
\text { Переліки пільгових категорій населення (пільга } \\
50 \% \text { та } 100 \% \text { ) } \\
\text { Перелік захворювань, у разі яких ЛЗ відпускаються } \\
\text { безоплатно }\end{array}$ & 7 \\
\hline $\begin{array}{l}\text { № } 955 \text { «Про заходи щодо стабілізації } \\
\text { цін на Л3 і медичні вироби» }\end{array}$ & 17.10.2008 & $\begin{array}{l}\text { Граничні націнки на Л3, що підлягають державному } \\
\text { регулюванню }\end{array}$ & 25 \\
\hline $\begin{array}{l}\text { № } 333 \text { «Деякі питання державного } \\
\text { регулювання цін на Л3 і ВМП» }\end{array}$ & 25.03.2009 & $\begin{array}{l}\text { Національний перелік ОЛ3 (у попередній редакції - } \\
215 \text { МНН, наразі затверджено новий Національний } \\
\text { перелік ОЛ3, містить } 427 \text { МНН за нозологіями) } \\
\text { Порядок фрормування цін }\end{array}$ & 9 \\
\hline $\begin{array}{l}\text { № } 240 \text { «Питання декларування зміни } \\
\text { оптово-відпускних цін на ЛЗ» }\end{array}$ & 2.07 .2014 & $\begin{array}{l}\text { Підлягають декларуванню зміни ОВЦ } \\
\text { урахування пез } \\
\text { закуповуються за бюджетні кошти }\end{array}$ & 7 \\
\hline $\begin{array}{l}\text { № } 73 \text { «Питання реалізації пілотного } \\
\text { проекту щодо запровадження } \\
\text { державного регулювання цін на } \\
\text { препарати інсуліну» }\end{array}$ & 5.03 .2014 & Загальний порядок проведення пілотного проекту & 5 \\
\hline $\begin{array}{l}\text { № } 862 \text { «Про державне регулювання } \\
\text { цін на лікарські засоби» }\end{array}$ & 9.11 .2016 & $\begin{array}{l}\text { Перелік ресрерентних країн для встановлення цін } \\
\text { на } 23 \text { МНН Л3, що входять до програми «Доступні } \\
\text { ліки». } \\
\text { Граничні націнки } 5 \text { \% та } 15 \text { \% (скасовано) }\end{array}$ & 8 \\
\hline $\begin{array}{l}\text { № } 180 \text { «Про внесення змін та } \\
\text { визнання такими, що втратили } \\
\text { чинність, деяких постанов КМУ» }\end{array}$ & 16.03 .2017 & $\begin{array}{l}\text { Національний перелік ОЛ3 (новий, відповідає } \\
\text { модельному переліку ВООЗ). Порядок закупівель } \\
\text { за Національним переліком }\end{array}$ & \\
\hline $\begin{array}{l}\text { № } 181 \text { «Про затвердження Порядку та } \\
\text { умов надання субвенції з державного } \\
\text { бюджету місцевим бюджетам на } \\
\text { відшкодування вартості ЛЗ для } \\
\text { лікування окремих захворювань» } \\
\end{array}$ & 10.03.2017 & $\begin{array}{l}\text { Фінансування формацевтичного забезпечення } \\
\text { хворих за урядовою програмою «Доступні ліки» }\end{array}$ & 2 \\
\hline
\end{tabular}

ISSN 2312-0967. Фармацевтичний часопис. 2020. № 1 
Фармацевтичне законодавство Pharmaceutical legislation

Продовження табл. 1

\begin{tabular}{|c|c|c|c|}
\hline 1 & 2 & 3 & 4 \\
\hline $\begin{array}{l}\text { № } 152 \text { «Про забезпечення доступності } \\
\text { лікарських засобів» }\end{array}$ & 17.03 .2017 & $\begin{array}{l}\text { Порядок повного чи часткового відшко-дування } \\
\text { вартості Л3 }\end{array}$ & 8 \\
\hline $\begin{array}{l}\text { № } 1080 \text { «Про внесення змін до деяких } \\
\text { постанов КМУ» }\end{array}$ & 27.12 .2017 & $\begin{array}{l}\text { Зміни до порядку срормування цін та оновлення } \\
\text { реєстру (один раз на рік) }\end{array}$ & 2 \\
\hline $\begin{array}{l}\text { № } 426 \text { «Про ресрерентне ціно- } \\
\text { утворення на деякі Л3, що } \\
\text { закуповуються за бюджетні кошти» }\end{array}$ & 03.04 .2019 & Порядок фрормування ресрерентних цін & 1 \\
\hline $\begin{array}{l}\text { № } 141 \text { «Про затвердження } \\
\text { Порядку використання коштів, } \\
\text { передбачених у державному бюджеті } \\
\text { на відшкодування вартості ЛЗ для } \\
\text { лікування окремих захворювань» }\end{array}$ & 27.02 .2019 & $\begin{array}{l}\text { Порядок використання коштів, передбачених у } \\
\text { державному бюджеті на відшкодування вартості } \\
\text { ЛЗ для лікування окремих захворювань }\end{array}$ & 1 \\
\hline $\begin{array}{l}\text { № } 135 \text { «Деякі питання реімбурсації } \\
\text { лікарських засобів» }\end{array}$ & 27.02 .2019 & $\begin{array}{l}3 \text { 01.04.2019 р. відшкодування вартості Л3 - за } \\
\text { електронними рецептами }\end{array}$ & 2 \\
\hline $\begin{array}{l}\text { № } 136 \text { «Деякі питання щодо договорів } \\
\text { про реімбурсацію» }\end{array}$ & 27.02 .2019 & $\begin{array}{l}\text { Порядок укладення, зміни та припинення договору } \\
\text { про реімбурсацію }\end{array}$ & 1 \\
\hline \multicolumn{4}{|c|}{ Накази МОз України } \\
\hline $\begin{array}{l}\text { № } 395 \text { «Про затвердження Методич- } \\
\text { них рекомендацій по визначенню } \\
\text { вартості виготовлення і фрасування лЗ } \\
\text { та ВМП» }\end{array}$ & 31.12 .1996 & Порядок розрахунку тарифів & 1 \\
\hline $\begin{array}{l}\text { № } 394 \text { Про затвердження Порядку } \\
\text { розрахунку граничного рівня ОВЦ на } \\
\text { ЛЗ для лікування осіб з гіпертонічною } \\
\text { хворобою та порівняльних } \\
\text { (рефрерентних цін) ...» }\end{array}$ & 29.05 .2012 & Механізм розрахунку граничних ОВЦ & 2 \\
\hline $\begin{array}{l}\text { № } 574 \text { «Про затвердження Поло- } \\
\text { ження про реєстр оптово-відпуск- } \\
\text { них цін на лікарські засоби і вироби } \\
\text { медичного призначення» }\end{array}$ & 18.08 .2014 & $\begin{array}{l}\text { Порядок ведення реєстру оптово-відпускних цін } \\
\text { на ЛЗ і ВМП, форма декларації зміни ОВЦ на лЗ }\end{array}$ & 1 \\
\hline $\begin{array}{l}\text { № } 84 \text { «Про затвердження Положення } \\
\text { про Національний перелік ОЛ3 ...» }\end{array}$ & 11.02 .2016 & Положення про Національний перелік ОлЗ & 2 \\
\hline $\begin{array}{l}\text { № } 1050 \text { «Про затвердження Поло- } \\
\text { ження про здійснення відбору Л3 для } \\
\text { внесення до Національного переліку } \\
\text { ОлЗ» }\end{array}$ & 07.10 .2016 & 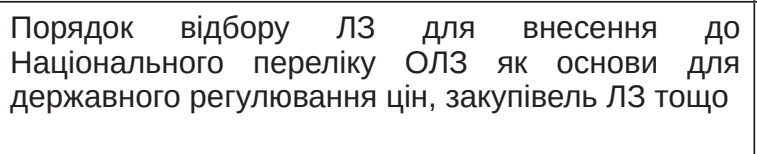 & 2 \\
\hline $\begin{array}{l}\text { № } 1423 \text { «Про затвердження Порядку } \\
\text { розрахунку граничних оптово- } \\
\text { відпускних цін на лікарські засоби на } \\
\text { основі ресрерентних цін» }\end{array}$ & 29.12 .2016 & $\begin{array}{l}\text { Порядок розрахунку ГрОВЦ на ліки на основі } \\
\text { ресрерентних цін }\end{array}$ & 4 \\
\hline $\begin{array}{l}\text { № } 299 \text { «Про внесення змін до Порядку } \\
\text { розрахунку граничних оптово- } \\
\text { відпускних цін на лікарські засоби на } \\
\text { основі ресрерентних цін» }\end{array}$ & 21.03 .2017 & $\begin{array}{l}\text { Зміни у розрахунках ГрОВЦ за DDD, ресрерентна } \\
\text { ціна визначається як медіана }\end{array}$ & 1 \\
\hline $\begin{array}{l}\text { № } 635 \text { «Про затвердження форми } \\
\text { Реєстру лікарських засобів, які } \\
\text { підлягають реімбурсації»» }\end{array}$ & 22.03 .2019 & $\begin{array}{l}\text { Форма реєстру така ж як у наказі 298, слово } \\
\text { «відшкодування» замінено на «реімбурсація» }\end{array}$ & 1 \\
\hline $\begin{array}{l}\text { № } 148 \text { «Про декларування зміни ОВЦ } \\
\text { на лікарські засоби станом на ..... p.» }\end{array}$ & 23.01 .2020 & Реєстр ОВЦ (систематично переглядається) & - \\
\hline $\begin{array}{l}\text { № } 316 \text { «Про затвердження } \\
\text { Реєстру Л3, вартість яких підлягає } \\
\text { відшкодуванню станом на 07.02.2020» }\end{array}$ & 13.02 .2020 & $\begin{array}{l}\text { Реєстр ЛЗ, вартість яких підлягає відшкодуванню } \\
\text { (переглядається систематично, кожного разу за } \\
\text { новим номером : № } 360 \text {, № } 856 \text {, № 111; № } 1367 ; \\
\text { № 148; № 1715) }\end{array}$ & - \\
\hline
\end{tabular}

ISSN 2312-0967. Pharmaceutical review. 2020. № 1 
Продовження табл. 1

\begin{tabular}{|l|l|l|c|}
\hline \multicolumn{1}{|c|}{1} & \multicolumn{1}{|c|}{ 2 } & \multicolumn{1}{|c|}{3} & 4 \\
\hline $\begin{array}{l}\text { № 1600 «Про деякі питання реде- } \\
\text { рентного ціноутворення на Л3, що } \\
\text { включені до Національного переліку } \\
\text { ОЛ3 та закуповуються за бюджетні } \\
\text { кошти» }\end{array}$ & 11.07 .2019 & $\begin{array}{l}\text { Порядок формування переліку Л3, на які } \\
\text { встановлюються граничні оптово-відпускні ціни } \\
\text { (обсяги закупівель 5 млн грн, перевищення ціни) }\end{array}$ & 1 \\
\hline $\begin{array}{l}\text { № 1713 «Перелік Л3, що включені до } \\
\text { Національного переліку ОЛ3 та на які } \\
\text { встановлюються граничні ОВЦ» }\end{array}$ & 29.07 .2019 & $\begin{array}{l}\text { 23 МНН Л3, які визначені за результатами аналізу } \\
\text { обсягів закупівель }\end{array}$ & 1 \\
\hline $\begin{array}{l}\text { № 13 «Реєстр граничних оптово- } \\
\text { відпускних цін на лікарські засоби } \\
\text { станом на 02.01.2020 р.» }\end{array}$ & 03.01.2020 & $\begin{array}{l}\text { Граничні оптово-відпускні ціни } \\
\text { DDD на «Доступні ліки» (за МНН) }\end{array}$ & 1 \\
\hline
\end{tabular}

У таблицю 2 включені документи, що регулювали окремі аспекти ціноутворення на Л3, але на даний момент втратили чинність.
Отже, аналіз свідчить, що питанням ціноутворення на ЛЗ приділяється особлива увага - протягом досліджуваного періоду було ухвалено 6 законів,

\section{Таблиця 2}

Нормативно-правові акти у сорері ціноутворення на лікарські засоби, що втратили чинність

\begin{tabular}{|c|c|c|c|}
\hline Нормативно-правові акти & Основні положення & $\begin{array}{l}\text { К-ть } \\
\text { ред. }\end{array}$ & $\begin{array}{c}\text { Якими } \\
\text { нормативно- } \\
\text { правовими } \\
\text { актами змінено/ } \\
\text { скасовано }\end{array}$ \\
\hline 1 & 2 & 3 & 4 \\
\hline \multicolumn{4}{|c|}{ Закони України } \\
\hline $\begin{array}{l}\text { «ро ціни та ціноутворення» від } \\
\text { 3.12.1990 р. }\end{array}$ & $\begin{array}{l}\text { Запроваджено ринкові принципи ціноутво- } \\
\text { рення, вільні, фріксовані та регульовані ціни }\end{array}$ & 12 & $\begin{array}{c}\text { Закон України } \\
\text { від 21.06.2016 р. }\end{array}$ \\
\hline \multicolumn{4}{|c|}{ Постанови КМУ } \\
\hline $\begin{array}{l}\text { № } 715 \text { «Про регулювання цін» від } \\
\text { 23.12.1992 р. }\end{array}$ & $\begin{array}{l}\text { ЛЗ віднесені до переліку товарів, за яким } \\
\text { виробники мають декларувати зміни цін. } \\
\text { Обласні ВО «Фармація» за погодженням } 3 \\
\text { органами виконавчої влади встановлюють } \\
\text { граничний рівень надбавок до оптових цін на } \\
\text { ЛЗ і ВМП }\end{array}$ & 9 & $\begin{array}{c}\text { ПКМУ № } 260 \\
\text { від 06.03.2019 }\end{array}$ \\
\hline $\begin{array}{l}\text { № } 403 \text { «Про внесення змін до } \\
\text { регулювання цін і тарифрів» від } \\
\text { 3.06.1993 р. }\end{array}$ & $\begin{array}{l}\text { Для Л3 встановлені граничні розміри } \\
\text { рентабельності (20 \% до собівартості). При } \\
\text { реалізації Л3 за рецептами знижка } 10 \%\end{array}$ & 3 & $\begin{array}{c}\text { ПКМУ № } 733 \\
\text { від 21.10.1994 }\end{array}$ \\
\hline $\begin{array}{l}\text { № } 1071 \text { «Про порядок закупівлі ЛЗ } \\
\text { закладами та установами ОЗ...» від } \\
\text { 5.09.1996 р. }\end{array}$ & «Бюджетний перелік» & 38 & $\begin{array}{l}\text { ПКМУ № } 180 \\
\text { від 16.03.2017 }\end{array}$ \\
\hline $\begin{array}{l}\text { № } 747 \text { «Про внесення змін і доповнень } \\
\text { до ПКМУ від 25.12.96 р. № 1548» від } \\
15.07 .1997 \text { р. }\end{array}$ & $\begin{array}{l}\text { Запроваджено регіональний принцип регу- } \\
\text { лювання рівнів торговельних надбавок на Л3 } \\
\text { та ВМП за переліком, визначеним МО3 та } \\
\text { Мінекономіки }\end{array}$ & 2 & $\begin{array}{c}\text { ПКМУ № } 333 \\
\text { від 25.03.2009 }\end{array}$ \\
\hline $\begin{array}{l}\text { № } 1499 \text { «Про внесення змін до деяких } \\
\text { Постанов КМУ» (зокрема, ПКМУ } \\
\text { № 1548) від 16.11.2001р. }\end{array}$ & $\begin{array}{l}\text { Граничні торговельні націнки на л3 (за } \\
\text { переліком) - } 35 \% \text { від оптової ціни вироб- } \\
\text { ника (митної вартості), що закуповують за } \\
\text { бюджетні кошти }-10 \%\end{array}$ & 3 & $\begin{array}{l}\text { ПКМУ № } 333 \\
\text { від 25.03.2009 }\end{array}$ \\
\hline $\begin{array}{l}\text { № } 1482 \text { «Про затвердження Націо- } \\
\text { нального переліку основних (життєво } \\
\text { необхідних) ЛЗ» 16.11.2001 }\end{array}$ & $\begin{array}{l}\text { Затверджено перелік Л3 за групами АTС- } \\
\text { класифрікації з метою забезпечити здійснення } \\
\text { моніторингу цін зазначених Л3 }\end{array}$ & 1 & $\begin{array}{l}\text { ПКМУ № } 400 \\
\text { 29.03.2006 p. }\end{array}$ \\
\hline $\begin{array}{l}\text { № } 400 \text { «Про затвердження Націо- } \\
\text { нального переліку ОЛЗ і ВМП» } \\
\text { 29.03.2006 р. }\end{array}$ & 783 найменування, у т. ч. екстемпоральні лЗ & & $\begin{array}{l}\text { ПКМУ № } 333 \\
\text { від 25.03.2009 }\end{array}$ \\
\hline
\end{tabular}

ISSN 2312-0967. Фармацевтичний часопис. 2020. № 1 
Продовження табл. 2

\begin{tabular}{|c|c|c|c|}
\hline 1 & 2 & 3 & 4 \\
\hline $\begin{array}{l}\text { № } 1154 \text { «Про встановлення граничних } \\
\text { рівнів цін на окремі лікарські засоби і } \\
\text { ВМП» від 30.10.2009 р. }\end{array}$ & $\begin{array}{l}3 \text { метою стабілізації цін на період епідемії } \\
\text { грипу A/Н1N1 установлені граничні ОВЦ і } \\
\text { роздрібні ціни на } 10 \text { л3 і } 5 \text { ВМП }\end{array}$ & 3 & $\begin{array}{l}\text { ПКМУ № } 819 \\
\text { від 08.09.2010 }\end{array}$ \\
\hline $\begin{array}{l}\text { № } 340 \text { «Про реалізацію пілотного } \\
\text { проекту щодо запровадження } \\
\text { державного регулювання цін на л3 } \\
\text { для лікування осіб із гіпертонічною } \\
\text { хворобою» від 25.04.2012 р. }\end{array}$ & $\begin{array}{l}\text { Перелік МНH лікарських засобів (у вигляді } \\
\text { таблеток та капсул) та їх комбінації, на які } \\
\text { поширюється дія пілотного проекту }\end{array}$ & 7 & ПКМУ \\
\hline $\begin{array}{l}\text { № } 794 \text { «Питання декларування змі- } \\
\text { ни ОВЦ на Л3, які закуповують за } \\
\text { рахунок коштів державного та місцевих } \\
\text { бюджетів» } 13.08 .12 \text { р. }\end{array}$ & $\begin{array}{l}\text { Порядок декларування змін оптово- } \\
\text { відпускних цін на ЛЗ і ВМП, що внесені до } \\
\text { бюджетного переліку }\end{array}$ & 3 & $\begin{array}{c}\text { ПКМУ № } 240 \\
\text { від 02.07.2014 }\end{array}$ \\
\hline $\begin{array}{l}\text { № } 907 \text { «Про затвердження Порядку } \\
\text { часткового відшкодування вартості } \\
\text { ЛЗ для лікування осіб з гіпертонічною } \\
\text { хворобою» від 5.09. } 2012 \text { р. }\end{array}$ & $\begin{array}{l}\text { Часткове відшкодування вартості ЛЗ - } \\
\text { на рівні затвердженої рефрерентної ціни } \\
\text { відшкодування } 3 \text { урахуванням граничних } \\
\text { надбавок }\end{array}$ & 5 & $\begin{array}{c}\text { ПКМУ № } 260 \\
\text { від 06.03.2019 }\end{array}$ \\
\hline $\begin{array}{l}\text { № } 554 \text { «Питання удосконалення } \\
\text { реалізації пілотного проекту ...» } \\
\text { 12.06.2013 р. }\end{array}$ & $\begin{array}{l}\text { Розподіл л3 на } 3 \text { групи: } 3 \text { відшкодуванням } \\
90 \text { \% вартості; } 3 \text { частковим відшкодуванням } \\
\text { та такі, що не відшкодовуються }\end{array}$ & 3 & $\begin{array}{c}\text { ПКМУ № } 260 \\
\text { від 06.03.2019 }\end{array}$ \\
\hline $\begin{array}{l}\text { № } 863 \text { «Про запровадження } \\
\text { відшкодування вартості ЛЗ» } \\
\text { 09.11.2016 р. }\end{array}$ & $\begin{array}{l}\text { Перелік МНH, що підлягають відшкодуванню } \\
\text { за програмою «Доступні ліки» }\end{array}$ & 6 & $\begin{array}{l}\text { ПКМУ № } 135 \\
\text { від 27.02.2019 }\end{array}$ \\
\hline \multicolumn{4}{|c|}{ Накази МОЗ України } \\
\hline $\begin{array}{l}\text { № 265/101 «Про затвердження Переліку } \\
\text { вітчизняних та імпортних ЛЗ і ВМП, ціни } \\
\text { на які підлягають держрегулюванню» } \\
\text { 01.08.1997р. }\end{array}$ & $\begin{array}{l}\text { «Ціновий перелік» містив } 90 \text { найменувань } \\
\text { ЛЗ, ціни на які підлягають державному } \\
\text { регулюванню (за МНН та за торговими } \\
\text { назвами) }\end{array}$ & 3 & $\begin{array}{c}\text { Наказ МО3 та } \\
\text { Мінекономіки } \\
\text { № 480/294 від } \\
\text { 03.12.2001 } \\
\end{array}$ \\
\hline $\begin{array}{l}\text { № 480/294 «Про затвердження Переліку } \\
\text { вітчизняних та імпортних ЛЗ і ВМП, ціни } \\
\text { на які підлягають держрегулюванню» } \\
\text { 03.12.2001р. }\end{array}$ & $\begin{array}{l}\text { Оновлений «Ціновий перелік». Контроль } \\
\text { покладено на Держцінінспекцію, Держкомітет } \\
\text { стандартизації, метрології та сертисрікації, } \\
\text { місцеві органи влади }\end{array}$ & 1 & $\begin{array}{l}\text { Наказ № } \\
\text { 490/ } 690 \text { від } \\
\text { 09.07.2009 }\end{array}$ \\
\hline $\begin{array}{l}\text { № } 1000 \text { «Про затвердження обов'яз- } \\
\text { кового мінімального асортименту } \\
\text { (соціально орієнтованих) ЛЗ і ВМП для } \\
\text { аптечних закладів» 29.12.2011 }\end{array}$ & $\begin{array}{l}\text { Регулюючий перелік - } 102 \text { МНН л3 та } 15 \\
\text { найменувань ВМП }\end{array}$ & 3 & $\begin{array}{l}\text { Наказ МО3 } \\
\text { № } 660 \text { від } \\
09.10 .2015\end{array}$ \\
\hline $\begin{array}{l}\text { № } 298 \text { «Про затвердження форми } \\
\text { Реєстру ЛЗ, вартість яких підлягає } \\
\text { відшкодуванню» від 21.03.2017 р. }\end{array}$ & Форма реєстру відшкодування & 1 & $\begin{array}{c}\text { Наказ № } 635 \\
\text { від 22.03.2019 }\end{array}$ \\
\hline
\end{tabular}

25 постанов КМУ, з них наразі залишаються чинними 14, а також більше 20 наказів МО3 (3 них наразі діють більше 10). Слід зазначити, що це лише основні документи, тобто не враховувалися численні НПА, що вносили певні зміни та доповнення до них, а також реєстри, які постійно змінюються із зміною номеру.

Відповідно до ієрархічного принципу найвищим за юридичною силою нормативним документом у сорері ціноутворення $є$ Закон України «Про ціни і ціноутворення» від 21.06.2012 р. № 5007-VI, який змінив попередню редакцію Закону від 3.12.1990 р. Закон визначає основні засади цінової політики і регулює відносини, що виникають у процесі формування, встановлення та застосування цін, а також здійснення державного контролю (нагляду) та спостереження у сорері ціноутворення. Відповідно до чинного законодавства України державні регульовані ціни запроваджуються на товари, які мають визначальний вплив на загальний рівень і динаміку цін, мають істотну соціальну значущість, такі ціни повинні бути економічно обґрунтованими (забезпечувати відповідність ціни на товар витратам на його виробництво, продаж (реалізацію) та прибуток від його продажу (реалізації).

Отже, об'єктом державного регулювання є ціни на Л3, які входять до відповідних регулюючих переліків. Наразі пріоритетним є Національний перелік ОЛЗ, затверджений ПКМУ № 333. У межах окремих пілотних проектів (щодо забезпечення інсулінами хворих на цукровий діабет) та урядових програм (Доступні ліки) встановлюються окремі правила. Для кращого контролю за цінами та відшкодуванням використову-

ISSN 2312-0967. Pharmaceutical review. 2020. № 1 


\section{Pharmaceutical legislation}

ються реєстри оптово-відпускних цін та реєстри відшкодування.

Слід зазначити, що до впровадження у 2017 р. нової редакції Національного переліку Ол3, державне регулювання цін здійснювалося за декількома переліками. Так, окрім Національного переліку Олз у попередній редакції, що містила 215 найменувань Лз за міжнародними непатентованими назвами, що відповідає 2682 найменуванням ЛЗ за торговельними назвами, існували «Бюджетний перелік», призначений для здійснення державних закупівель (затверджений ПКМУ № 1071), що містив 784 найменування за МНH (8900 найменувань Л3 за торговельними назвами, а також Л3, що виготовлялися в аптеці). Також існував «Обов'язковий мінімальний асортимент (соціально орієнтованих) ЛЗ і ВМП для аптечних закладів», затверджений Наказом МО3 від 29.12.2011 р. № 1000, що містив 102 МНН Л3 та 15 ВМП. Існування декількох паралельних регулюючих переліків призводило до виникнення певних колізій та було незручним для застосування.

Наразі одним з основних документів, що визначає основні методичні підходи до встановлення цін на Л3, які підлягають регулюванню, є ПКМУ від 17.10.2008 р. №955 «Про заходи щодо стабілізації цін на лікарські засоби», назва якої говорить сама за себе. Цей нормативний документ був прийнятий урядом як відповідь на неконтрольоване зростання цін під час економічної кризи 2008 р.

На той час з метою зниження цін на ЛЗ, включені до Національного переліку ОЛЗ (ПКМУ № 400 від 29.03 .2006 р.), граничні постачальницько-збутові надбавки були встановлені не вище ніж $15 \%$, а роздрібні - не вище 35 \% оптової ціни виробника (митної вартості) з урахуванням знижок. Для лз, включених до «цінового» переліку (наказ МО3 і Мінекономіки № 480/294 від 3.12.2001р.) - $10 \%$ та $15 \%$; а у разі закупівель за бюджетні кошти - 10 \% та 10 \% відповідно.

Контроль за цінами було покладено на Державну інспекцію з контролю якості Л3, при цьому передбачалося запровадження декларування виробником або імпортером оптової ціни (митної вартості) ЛЗ і ВМП, створення державного реєстру цін як єдиної інфрормаційної бази даних.

Слід зазначити, що постанова № 955 не втрачає актуальності й до сьогодні. Протягом останніх 10 років зміни до даної постанови вносили більше 20 разів, що суттєво змінило підходи та методи фрормування цін. Наразі постанова № 955 передбачає наступне: на Лз, включені до Національного переліку ОЛ3, граничні постачальницько-збутові надбавки становлять не вище ніж $10 \%$, що нараховуються до оптововідпускної ціни (ОВЦ) з урахуванням податків та зборів. Граничні торговельні (роздрібні) надбавки визначаються за регресивною шкалою, виходячи із закупівельної ціни з урахуванням податків: до 100 грн -
25 \%, 100-500 грн - $20 \%$, 500-1000 грн - $15 \%$, більш ніж 1000 грн - 10 \%. Слід зазначити, що вказані правила не поширюються на наркотичні, психотропні Л3, прекурсори та медичні гази. При здійсненні публічних закупівель Лз (які входять до Національного переліку ОЛ3), розмір граничних постачальницько-збутових надбавок має становити не вище ніж $10 \%$, що нараховуються до ОВЦ з урахуванням податків та зборів, а роздрібних - не вище ніж 10 \% до закупівельної ціни з урахуванням податків. На ЛЗ, включені до урядової програми «Доступні ліки», граничні постачальницько-збутові надбавки становлять 10\% до ОВЦ 3 урахуванням податків, а граничні торговельні (роздрібні) надбавки - 15 \% до закупівельної ціни з урахуванням податків.

Постанова КМУ № 333 «Деякі питання державного регулювання цін на лікарські засоби і вироби медичного призначення», ухвалена 25.03.2009 р., була спрямована на зниження кризових явищ. Відповідно до постанови був затверджений Національний перелік ОЛЗ як один з пріоритетних (215 МНH), при цьому було суттєво змінено порядок формування цін на ЛЗ (внесено зміни до ПКМУ № 955). Так, на препарати 3 Національного переліку гранична оптова націнка становила $12 \%$ до оптово-відпускної ціни, а роздрібна - 25 \% до закупівельної. Це не стосувалося Л3, якщо ціна була нижче 12 грн (крім Л3, що закуповувалися за бюджетні кошти).

Механізм декларування оптово-відпускних цін (ОВЦ) регламентовано ПКМУ від 2.07.2014 р. № 240 «Питання декларування зміни оптово-відпускних цін на ЛЗ» та фрункціонує за заявницьким принципом. Власники реєстраційних посвідчень декларують ціни на Л3, які закуповуються та/або вартість яких відшкодовується за бюджетні кошти. Це $є$ обов'язковою умовою оплати товару за рахунок бюджетних коштів. При цьому фрактичний розмір ОВЦ на кожну лікарську форму, дозування, споживчу упаковку лз не повинен перевищувати розміру внесеної до відповідного реєстру ОВЦ. 303, що повністю або частково фрінансуються 3 державного та місцевих бюджетів, закуповують лз за цінами, які не перевищують рівня задекларованих змін ОВЦ з урахуванням податків та зборів, а також граничних надбавок. Чинний механізм декларування цін, на наш погляд, не $є$ еорективним, потребує перегляду та вдосконалення.

Наступним важливим етапом було впровадження референтного ціноутворення та пілотних проектів для забезпечення доступності ОЛз.

Перший пілотний проект із державного регулювання цін на гіпотензивні ліки був реалізований у 20122014 рр. До вказаного проекту увійшли 10 МНН. При декларуванні ОВЦ розраховувалися порівняльні ціни 3 урахуванням DDD в таких референтних країнах: Болгарія, Молдова, Польща, Словаччина, Чехія (основні) та Латвія, Сербія та Угорщина (резервні).

ISSN 2312-0967. Фармацевтичний часопис. 2020. № 1 
Відшкодування вартості Лз здійснювалося за трьома ціновими групами: 1) Л3, вартість яких підлягає відшкодуванню на 90 \%; 2) відшкодування на 60-80 \%; 3) вартість не відшкодовується. В результаті реалізації проекту зменшилися показники захворюваності на інсульт (у 2013 р. на 6 \% порівняно $з 2012$ р.), а також кількість викликів швидкої медичної допомоги з приводу гіпертонічних кризів - на 16 \% [11]. Зросла прихильність пацієнтів до лікування, а лікарів - до виписування рецептів.

Пілотний проект із забезпечення інсулінами хворих на цукровий діабет діє з 2016 р. Розрахунки референтних цін повного відшкодування відрізняються для препаратів вітчизняного та іноземного виробництва. Референтні країни - Болгарія, Молдова, Польща, Словаччина, Чехія, Латвія, Сербія, Угорщина. Реєстр рефрерентних цін (цін відшкодування) на препарати інсуліну містить близько 70 позицій. Вид відшкодування (повне чи часткове) визначається належністю пацієнта до однієї з 11 категорій хворих, що внесені до реєстру.

У зв'язку з впровадженням Урядової програми «Доступні ліки» 9.11.2016 р. Кабінетом Міністрів було прийнято 2 постанови: «Про державне регулювання цін на лікарські засоби» (постанова КМУ № 862) та «Про запровадження відшкодування вартості лікарських засобів» (постанова КМУ № 863), відповідно до яких впроваджувалося державне регулювання цін на $21 \mathrm{MHН} \mathrm{Л3} \mathrm{для} \mathrm{лікування} \mathrm{цукрово-}$ го діабету 2 типу, серцево-судинних захворювань (СС3) та бронхіальної астми. Пізніше перелік було доповнено і наразі він містить $23 \mathrm{MHH}$. За наявності рецепта лікаря пацієнти мають змогу придбавати лз безоплатно або з доплатою. Залучення аптечних закладів та виробників ЛЗ до програми «Доступні ліки» відбувається на добровільних засадах. 3 1.04.2019 р. адміністрування урядової програми здійснює Національна служба здоров'я України (НСЗУ), а відшкодування вартості ЛЗ здійснюється тільки за електронними рецептами.

Таким чином, аналіз пілотних проектів та урядової програми «Доступні ліки» свідчить про відсутність єдиних підходів щодо розрахунку референтних цін та встановлення граничних націнок, а також порядку реімбурсації. 3 метою удосконалення механізму рефрерентного ціноутворення на всіх етапах реалізації пілотних проектів має бути реалізовано можливість зворотного зв'язку та коригування дій 3 урахуванням аналізу соціальної та економічної ефрективності.

Кафедрою організації та економіки фрармації НФаУ проводяться дослідження, присвячені впровадженню оцінки технологій охорони здоров'я та удосконаленню ціноутворення на ліки, у тому числі в рамках пілотних проектів та урядових програм. За результатами наукових досліджень, проведених науковцями кафредри, зокрема, бюджетної НДР «Рефрормування охорони здоров'я: удосконалення соціально-економічних механізмів підвищення доступності ЛЗ та програма впровадження оцінки медичних технологій» (2014-2016 рр.) розроблено та впроваджено в практику 9 методичних рекомендацій з реімбурсації вартості Л3 (2007), проведення державної експертизи та декларування оптово-відпускних цін на ОЛ3 (2008), з фрормування системи ресрерентних цін на ОЛЗ (2010), з проведення моніторингу цін на Л3, що закуповуються за державними цільовими програмами (2011), з визначення тарифів за індивідуальне та серійне виготовлення екстемпоральних ліків в аптеках (2015), фрормування галузевого стандарту з проведення оцінки технологій охорони здоров'я (2015), які використані під час підготовки постанов КМУ та наказів МОЗУ. Проведено наукове обґрунтування та розрахунки для пілотних проектів щодо державного регулювання цін на соціально важливі групи лікарських засобів (серцево-судинні захворювання, діабет, бронхіальна астма, онкологія). Також 3 метою забезпечення доступності Лз робочою групою вчених Національного фрармацевтичного університету розроблено проект Концепції Державної цільової програми «Імпортозаміщення лікарських засобів в Україні на 2017-2027 роки». Обґрунтовані методичні підходи до впровадження системи оцінки технологій охорони здоров'я.

Для створення ефективної системи цінового регулювання важливо комплексно підійти до питання оптимізації нормативно-правової бази, яка наразі $€$ багатовекторною та надто складною. Офрісом ефективного регулювання у 2018 р. була підготовлена Зелена книга [12], у якій представлені результати «інвентаризації» нормативно-правових актів за напрямами. На жаль, лише незначну частку НПА у сфері регулювання фрармацевтичного ціноутворення було переглянуто.

3 метою виявлення закономірностей застосування різних НПА нами було проведено їх систематизацію за ознаками поставлених цілей (рис. 1).

Висновки. Нормативно-правова база, що регулює питання забезпечення доступності ЛЗ та ціноутворення на ліки дуже складна і суперечлива, часто змінюється. 3 метою створення ефективної системи цінового регулювання пропонується оптимізувати нормативно-правову базу в напрямку кодиорікації (створення кодексу), що дозволило б оперативно вносити зміни та уникати правових колізій.

На нашу думку, доцільно оптимізувати нормативно-правову базу за принципом кодифікації, згрупувавши НПА за певними напрямами (аспектами) регулювання. Наприклад, сорормувати єдиний документ, присвячений реалізації урядової програми «Доступні ліки», який містив би перелік ЛЗ, що підлягають відшкодуванню, перелік референтних країн, порядок формування оптово-відпускних цін та граничні націнки

ISSN 2312-0967. Pharmaceutical review. 2020. № 1 


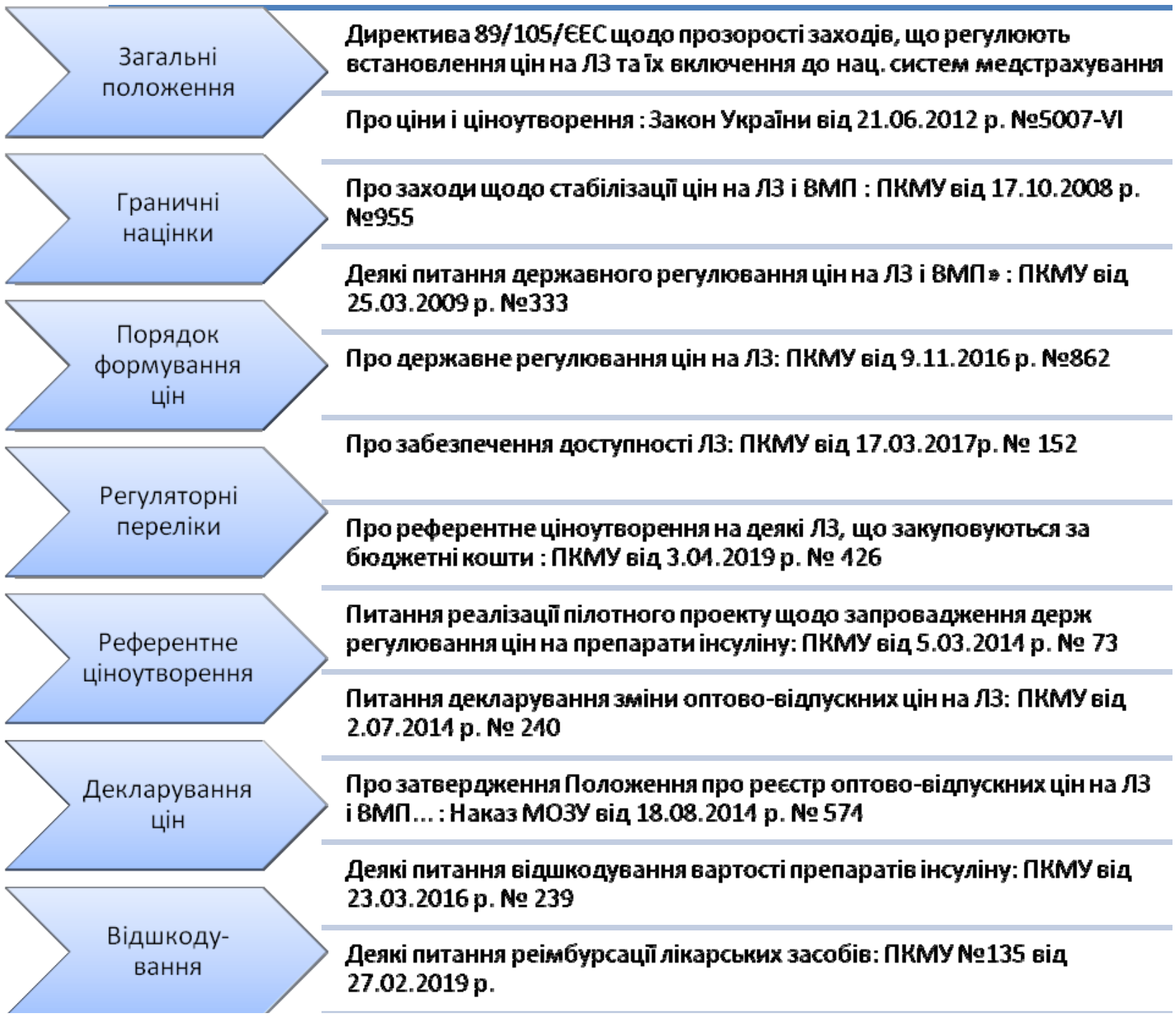

Рис. 1. Аналіз сучасної нормативно-правової бази щодо регулювання цін на лікарські засоби.

на лЗ, відповідний реєстр відшкодування (оновлювати також без постійної зміни номерів наказів), а також порядок призначення, відпуску Лз та відшкодування л3, обліку та звітності та інших організаційних аспектів. Це дозволить уникнути дублювання та супереч- ностей у трактуванні певних правових норм, а також, безперечно, сприятиме еоективності регулювання.

Конфлікт інтересів: відсутній.

Conflicts of interest: author has no conflict of interest to declare.

\section{RESEARCH OF LEGISLATIVE BASE IN ENSURING THE AVAILABILITY OF MEDICINES FOR POPULATION}

\section{M. Nazarkina}

National University of Pharmacy, Kharkiv

victory.nazarkina@gmail.com

The aim of the work. To analyze and systematize the legal framework in the field of ensuring the availability of medicines for the population.

ISSN 2312-0967. Фармацевтичний часопис. 2020. № 1 
Materials and Methods. Regulatory acts, analytical documents, official sites of the authorities, scientific works of domestic scientists on state regulation of pricing on drugs; analysis historical, logical, generalization and systematization.

Results and Discussion. In the context of providing the state with guarantees of availability of medical and pharmaceutical care for the population, the state regulation of prices for medicines is carried out by declaring prices, limiting margins, reference pricing. In the absence of compulsory health insurance in Ukraine pilot projects and government programs are being launched to increase the availability of medicines to the general public. During the period of independence the state adopted a number of legal acts in the field of pharmaceutical pricing: $25 \mathrm{CMU}$ Resolutions, more than 20 orders of the Ministry of Health of Ukraine. According to the results of the survey of pharmacy workers, frequent change and contradiction of the regulatory framework is one of the main problems, which causes the low efficiency of the state regulation of pharmaceutical activity. This, in turn, affects the quality of providing pharmaceutical care for the population.

Conclusions. The regulatory framework governing the availability of drugs and the pricing of drugs is very complex and controversial, often changing. In order to create an effective system of price regulation, it is proposed to optimize the legal framework in the direction of codification (creation of a code), which would allow to make changes promptly and avoid legal conflicts.

Key words: pricing; medicines; availability of medicines; legal framework; state regulation; legal act.

\title{
ИССЛЕДОВАНИЕ НОРМАТИВНО-ПРАВОВОЙ БАЗЫ В СФЕРЕ ОБЕСПЕЧЕНИЯ ДОСТУПНОСТИ ЛЕКАРСТВ ДЛЯ НАСЕЛЕНИЯ
}

\author{
В. Н. Назаркина \\ Национальный фрармацевтический университет, Харьков \\ victory.nazarkina@gmail.com
}

Цель работы. Анализ и систематизация нормативно-правовой базы в сфере обеспечения доступности лекарств для населения.

Материалы и методы. Нормативно-правовые акты (НПА), аналитические документы, официальные сайты органов власти, научные труды отечественных ученых по государственному регулированию ценообразования на лС; анализ исторический, логический, обобщение и систематизация.

Результаты и обсуждение. В контексте обеспечения государством гарантий доступности медицинской и фрармацевтической помощи населению осуществляется государственное регулирование цен на лекарства путем декларирования цен, установления предельных наценок, референтного ценообразования. В условиях отсутствия в Украине обязательного медицинского страхования внедряются пилотные проекты и правительственные программы по повышению доступности лекарств для населения. За период независимости государством принят целый ряд НПА в сорере фрармацевтического ценообразования, а именно: 25 Постановлений КМУ, более 20 приказов МОЗ Украины. По результатам опроса работников аптек, частая смена и противоречивость нормативной базы является одной из основных проблем, которая обусловливает низкую эфффективность системы государственного регулирования фрармацевтической деятельности. Это, в свою очередь, влияет на качество предоставления фрармацевтической помощи населению.

Выводы. С целью создания эсффективной системы ценового регулирования предлагается оптимизировать нормативно-правовую базу в направлении кодификации, что позволило бы оперативно вносить изменения, избегать правовых коллизий и в итоге повысить качество и доступность фармацевтической помощи для населения.

Ключевые слова: ценообразование; лекарственные препараты; доступность лекарств; нормативно-правовая база; государственное регулирование; нормативно-правовой акт.

\section{Список бібліографічних посилань}

1. Global Health Observatory (GHO) data. Available from: https://www.who.int/gho/database/en/

2. Демографрічна та соціальна статистика. Охорона здоров'я. URL: http://www.ukrstat.gov.ua/

3. Немченко А. С., Косяченко К. Л., Немченко О. А. Ціноутворення на лікарські засоби. Харків : Апостроф, 2012. 304 C.

4. Немченко А. С., Назаркіна В. М. Обґрунтування моделі ціноутворення на лікарські засоби за умов впровадження оцінки технологій охорони здоров'я.
Київ : МО3, 2015. 23 с.

5. Немченко А. С., Куриленко Ю. Є. Аналіз нормативноправових актів щодо державного регулювання цін на лікарські засоби для лікування серцево-судинних захворювань. Соціальна фрармація в охороні здоров'я. 2017. 3 (3). С. 12-20.

6. Немченко, А. С., Царева К. О., Хоменко В. М. Аналіз нормативно-правових актів щодо державного регулювання цін на лікарські засоби в Україні. Соціальна фрармація: стан, проблеми та перспективи : матер.

ISSN 2312-0967. Pharmaceutical review. 2020. № 1 


\section{Pharmaceutical legislation}

наук. симпозіуму у рамках VIII Нац. з'їзду фрармацевтів України, 15-16 верес. 2016 р. Харків, 2016. С. 127-129.

7. Дешко Л. М. Державне регулювання цін на лікарські засоби в Україні: історико-правовий аналіз. Медичне право України: проблеми становлення та розвитку : матер. I Всеукр. наук.-практ. конфр. 19-20 квітня 2007 р. Львів, 2007. С. 120-126.

8. Council Directive 89/105/EEC of 21 December 1988 relating to the transparency of measures regulating the prices of medicinal products for human use and their inclusion in the scope of national health insurance systems Available from: https://eur-lex.europa.eu/legalcontent/EN/TXT/?uri=CELEX\%3A31989L0105

\section{References}

1. Global Health Observatory $(\mathrm{GHO})$ data. Available from: https://www.who.int/gho/database/en/

2. [Demographic and social statistics. Health care]. Available from: http://www.ukrstat.gov.ua/ Ukrainian.

3. Nemchenko AS, Kosiachenko KL, Nemchenko OA. Pricing for medicines. [Ціноутворення на лікарські засоби] Kharkiv: Apostrof; 2012. Ukrainian.

4. Nemchenko AS, Nazarkina VM. Substantiation of the model of pricing for medicines under the condition of introduction of Health Technology Assessment. [Обґрунтування моделі ціноутворення на лікарські засоби за умов впровадження оцінки технологій охорони здоров'я] Kyiv: Ministry of Health; 2015. Ukrainian.

5. Nemchenko AS, Kurylenko YuYe. [Analysis of regulatory acts on state regulation of prices for medicines for the treatment of cardiovascular diseases]. Sotsialna farmatsiia v okhoroni zdorovia. 2017;3(3): 12-20. Ukrainian.

6. Nemchenko AS, Tsareva KO, Khomenko VM. Analysis of regulations on state regulation of prices for medicines in Ukraine. Social pharmacy: status, problems and prospects: Proceedings of the scientific symposium at the VIII National congress of the pharmacists, 2016 Septem 15-6; Kharkiv. Kharkiv; 2016. P. 127-9. Ukrainian.
9. Немченко А. С., Назаркіна В. М., Куриленко Ю. $€$. Законодавство в системі охорони здоров'я: навч. посіб. Харків : НФаУ, 2019. 84 с.

10. Законодавство України. URL : https://zakon.rada.gov. ua/laws/show

11. Лікування артеріальної гіпертензії та нагляд за безпекою й ефективністю антигіпертензивних препаратів / Нетяженко В. та ін. URL : https://www. apteka.ua/article/289016

12. Зелена книга. Аналіз державного цінового регулювання. Київ, Офріс ефективного регулювання, 2018. URL : https://brdo.com.ua/

7. Deshko LM. State regulation of drug prices in Ukraine: a historical and legal analysis. Medical Law of Ukraine: Problems of Formation and Development: Proceedings of the 1st All-Ukrainian scientific and practical conference, 2007 April 19-20; Lviv. Lviv; 2007. P. 120-6. Ukrainian.

8. Council Directive 89/105/EEC of 21 December 1988 relating to the transparency of measures regulating the prices of medicinal products for human use and their inclusion in the scope of national health insurance systems. Available from: https://eur-lex.europa.eu/legalcontent/EN/TXT/?uri=CELEX\%3A31989L0105

9. Nemchenko AS, Nazarkina VM, Kurylenko YuYe. Legislation in the health care system [Законодавство в системі охорони здоров'я] Kharkiv: NFaU: 2019. Ukrainian.

10. Legislation of Ukraine. Available from: https://zakon. rada.gov.ua/laws/show Ukrainian.

11. Netiazhenko V. Treatment of arterial hypertension and supervision of safety and efficacy of antihypertensive medicines. Available from: https://www.apteka.ua/article/289016 Ukrainian.

12. Green Paper. Analysis of the state price regulation. Kyiv, Office of effective regulation; 2018. Available from: https://brdo.com.ua/ Ukrainian.

\section{Відомості про автора}

Назаркіна В. М. - канд. фрармац. н., доц., доцент кафедри організації та економіки фрармації, Національний фрармацевтичний університет, Харків. E-mail: victory.nazarkina@gmail.com, ORCID 0000-0002-0767-6180.

\section{Information about the author}

Nazarkina V. M. - PhD (Pharmacy), Associate Professor of the Department of Organization and Economy of Pharmacy, National University of Pharmacy, Kharkiv. E-mail: victory.nazarkina@gmail.com, ORCID 0000-0002-0767-6180. 